\title{
Is There Any Difference of Financial Features between Bidder and Target Banks in Nigeria Mergers and Acquisitions?
}

\author{
Bukar Umar Bolori \\ Department of Banking and Finance, Ramat Polytechnic Maiduguri, Borno State, Nigeria \\ Email: boloribukarumar@gmail.com
}

How to cite this paper: Bolori, B.U. (2018) Is There Any Difference of Financial Features between Bidder and Target Banks in Nigeria Mergers and Acquisitions? Open Access Library Journal, 5: e4729. https://doi.org/10.4236/oalib.1104729

Received: June 19, 2018

Accepted: September 17, 2018

Published: September 20, 2018

Copyright (c) 2018 by author and Open Access Library Inc.

This work is licensed under the Creative Commons Attribution International License (CC BY 4.0).

http://creativecommons.org/licenses/by/4.0/

\section{(c) (i) Open Access}

\begin{abstract}
The Nigerian Banking sector has suffered problematic times since 1999, when the sector was facing problems of corporate governance as identified by the Central Bank of Nigeria. However, CBN started embarking on a comprehensive reform agenda since that time and many measures have been taken to bring the sector on the right track by imposing an IMF Code of Good Practices on Transparency in Monetary and Financial policies. Mergers and Acquisitions ( $\mathrm{M} \& \mathrm{~A}$ ) is a process "where two or more companies are combined to achieve certain strategic and business objectives". Therefore, Merger and Acquisition seems as a means of achieving business and strategy objectives. The study examined the differences of financial features among bidder and target banks in the Nigerian commercial banking sector. The findings of paired t-test on financial features among bidder and target banks show that bidders and targets' mean of each variable and financial features between bidder and target banks for 3 years (2002-2004) average indicates that bidders and targets' mean of each variable are statistically different at $5 \%$. Similarly, the findings for bidder banks' performance of 5 years (2000-2004) before and 5 years (2006-2010) after mergers and bidder banks' performance of 3 years (2002-2004) before and 3 years after mergers (2006-2008) are also statistically different at $5 \%$. The study recommends that managers of large and efficient banks seeking to go for merger and acquisition should halt from targeting small and less efficient banks because it will lead to operational inefficiency.
\end{abstract}

\section{Subject Areas}

Economics

\section{Keywords}

Merger, Acquisition, Financial Features, Bidder Bank, Target Banks, Nigeria 


\section{Introduction}

Mergers and Acquisitions ( $M \& A$ ) remains a subject of concern to business, industry and scholars [1]. "Mergers and acquisitions is not new; the tool has been used since 1890s. Mergers and Acquisitions is the instrument used by companies to increase their global reach and competitiveness" [2]. "The financial crisis has affected the landscape of the banking sector around the world" [3]. The impact of global financial crisis in the 1990s was one of the escalating forces that brought about M \& As as a tool for consolidation [4] [5] [6]. Of what significance do mergers and acquisitions have on individual shareholders and corporate firms?

An array of studies showed that mergers and acquisitions has a significant impact on corporate businesses, however, few studies were conducted on the impact it has on individuals acquiring shareholders particularly in terms of financial gain. Indeed, although the transformation of $\mathrm{M} \&$ As is not a straight forward process, and as a remediation tool has been transformed in recent years [7] [8] [9] [10]. Furthermore, the efficacy of $\mathrm{M} \& \mathrm{~A}$ in consolidating business is still contested. On the one hand, it has been pointed out that Mergers and Acquisitions is a popular means of growth of a business [11]. While Sevenius [12] found that $M$ \& As increases additional market shares, from a contrary view, $M$ \& A serves as a synergy in a business [13] [14]. In 2007 alone, the number of $M$ \& As' deals announced worldwide was 35,982 which accounts for an aggregate deal value of approximately $£ 802.60 \mathrm{GPB}$ billion in the USA and $£ 1821.82 \mathrm{GPB}$ billion in Europe [11]. Harford [15] believes that mergers waves in the aggregate rise when several industries undergo concurrent shocks that make mergers more profitable.

On the other hand, certain studies found that the average mergers and acquisitions waves have yielded unprofitable outcomes because they were unable to achieve their desire objectives [16] [17] [18] [19]. Sudarsanam [20] argues that "mergers and acquisitions more often destroys rather than enhances value for the acquirer shareholders". However, do M \& As really create value? Teply and Starova [21] are of opinion that Mergers and Acquisitions can create value to the targets rather than the bidders. Against this back drop, despite its shortcomings, it is apparent that M \& As plays an inevitable role in shaping and boosting businesses. Therefore, it is a tactical alternative to achieve business strategy. Given the pros and cons surrounding $M \&$ As in business, this study examines the differences of financial features among bidder and target banks in the Nigerian commercial banking sector. The hypotheses of the study were: mergers and acquisitions improved acquiring shareholders values; and mergers and acquisitions do not improved acquiring shareholders values.

\section{Overviews of Mergers and Acquisitions in the Nigerian Banking Sector}

The Nigerian Banking sub-sector has suffered problematic times since 1999, 
when the sector was facing problems of corporate governance as identified by the Central Bank of Nigeria. However, CBN started embarking on a comprehensive reform agenda since that time and many measures have been taken to bring the sector on the right track by imposing an IMF Code of Good Practices on Transparency in Monetary and Financial policies, the need to concentrate on developing the human resources capacity and adaptation of modern technology such as computerising the banking system in order to enhance efficiency and effectiveness in fulfilling the modern and international requirement, embarked on continuing supervising and regulating a role to ensure effective corporate governance by ascertaining that proper and qualified individuals are appointed into both the top management and boards of the respective financial institutions and also ensuring any unethical or profession misconduct would serve sanctions accordingly [22].

However, in spite of all the above measures, financial institutions were still characterised by their inability to pay workers' salaries and benefits, very low profit margins or even losses, inability to carry out debts services, retrenchment, low productivity, etc. [23] [24]. The decadence persisted up to the year 2004, when the regime at that time came up with a new approach of addressing the problems. Previously, from 1985 to 1991, the number of Nigerian commercial banks grew from 40 up to 120 and unfortunately after four years, some of them encountered problems and as a result their licenses were revoked by the Central Bank of Nigeria. This event inevitably had serious consequences on the economy of the country [23]. The banks' failure was caused by several factors, such as insufficient working capital, poor management, poor regulation, government politics and others [23]. In 2004, the CBN came up with new banking reform policy, which was to be implemented in two main phases:

\subsection{The First Phase}

Consolidating and strengthening the Nigerian banking system: This was to create a strong, reliable and diversified banking sphere which would ascertain the safety of deposits, influencing economic development and equally making the sector competent and capable of competing regionally and globally in the financial world. These would influence high returns to the investors and serve as an effective source of finance to businesses in the country. An effective banking system would normally attract foreign capital investments which would eventually influence general development in Nigeria. However, a position would place the country as a good competitive player in the $21^{\text {st }}$ century. As witnessed in recent past, there has been financial globalisation of the banking system through mergers and acquisitions [5] [6]. The consolidation of corporations can be achieved through mergers and acquisitions with the help of recapitalisation and proactive regulation [4].

CBN [25] stated that "mergers and acquisitions especially in the banking industry is now a global phenomenon. Looking at the United State of America, 
there had been over 7000 cases of bank mergers since 1980, while the same trend occurred in the United Kingdom and other European countries. Especially, in the period 1997 to 1998, 203 banks mergers and acquisitions took place in the Euro area. Cross-country mergers are also taking hold. In 1998 a merger in France resulted in a new bank with a capital base of US $\$ 688$ billion [ $£ 535.66$ billion GBP], while the merger of two banks in Germany in the same year created the second largest bank in Germany with a capital base of US \$541 billion [£421.21 billion GBP]. In many emerging markets including Argentina, Brazil and Korea, consolidation has also become prominent, as banks strive to become more competitive and resilient to shocks as well as the repositioning of their operations to cope with the challenges of the increasingly globalised banking systems. In South Korea, for example, the system was left with only 8 commercial banks with about 4500 branches after consolidation". In Nigeria, there were 89 banks and the majority of them with a capital base of less than US\$ 10 million ( $£ 7.79$ million GBP), and having about 3300 branches. In comparing this to South Korea banks, 8 banks had about 4500 branches and in South Africa, one bank with a larger asset base of more than entire 89 Nigerian banks worth [25].

However, the adoption of Mergers and Acquisitions might be necessary for the consolidation and strengthening of Nigerian banks. The reform agenda includes-the stability of exchange rate and price and financial sector diversification [26]. The recent CBN assessment in 2004, carried out on commercial banks showed that out of 89 banks, 62 were rated as satisfactorily sound, 14 were at marginal level while 11 were rated unsound and 2 rated as totally weak because they did not deliver any return for that period. A further investigation of the banks in both their returns and efficiency reveals that the banking system has 19.2 per cent of total assets, total deposit liabilities of 17.2 per cent while 19.5 per cent of the non-performing assets. The situation was put under supervision.

The Central Bank of Nigeria issued an ultimatum, with a time limit 18 months, to all the commercial banks in Nigeria to have a minimum capital requirement of N25 billion (Nigerian Naira) [ $£ 53.8$ million GBP] that is, before the end of 2005. In view of this, the CBN collaborated with certain institutions such as NDIC, SEC, NSE, the financial authorities and legal/regulation frameworks in order to facilitate the consolidation process. Eventually, the recapitalisation exercise rendered mergers and acquisitions as necessary instruments of consolidation for most of the banks, because at the end of 2005, only 25 banks survived out of 89 and the majority made it through regulatory mergers and acquisitions but their number later fell to 24 via market-induced merger and acquisition. Of the 2900 branches of the 89 Nigerian banks, only 24 branches succeeded, and these have 5500 branches [27] [28].

\subsection{The Second Phase}

The CBN's last phase of the Nigerian banking reform attempts to address issues of diversification, including programmes to encourage the emergence of regional 
and unit or specialised banks [25]. The financial crisis, which started as the bursting of the housing bubble in the United States in 2007 later escalated into a global economic crisis as a contagion and affected many countries and sectors extensively, including Nigeria [28]-[35].

However, the distress in the Nigerian banking system was amplified by the contagion as a liquidity crisis and in view of such CBN improvised several measures to deal with the development. Therefore, Central Bank of Nigeria responded to the development by improvising the following measures:

- 10.25 per cent to 9.75 per cent reduction in Monetary Policy Rate (MPR).

- 4.0 per cent to 2.0 per cent reduction in Cash Reserve Requirement (CRR).

- 40 per cent to 30 per cent reduction in the Liquidity Ratio (LR).

- Option issued to the interested banks to restructure their margin loans up till 2009.

- 360 days extension grace of lending facilities was issued to banks.

- Expanded discount window was introduced in order to allow additional instruments.

- Liquidity mopping-up was halted or suspended in 2008.

- A serious emphasis was stressed on the code of corporate Governance promulgated by the CBN in order to promote accountability and transparency in all the banks in the country.

- The CBN reviewed a contingency plan for taxonomic distress in banks.

Despite the reform efforts, however, the Nigerian banking sector system remained fragile, as the measures failed to address their challenges. Problems in nine of the 86 Nigerian banks, for example, could not be solved through liquidation thus as argued by Sanusi [28], "if drastic action is not taken, the financial system could collapse". After a comprehensive analysis of the situation, the CBN in collaboration with the Federal Ministry of Finance (MOF) and NDIC interposed N620 billion ( $£ 2.24 \mathrm{GBP}$ ) into the nine affected banks.

In addition, the executive directors of those banks were withdrawn and replaced with technical expertise. All of these are with the goal of curtailing corruption and improving the efficiency and performance in the banking sector. There has been a very close monitoring of the banks by the CBN. Later, other reform measures were adopted in order to create financial sector stability, enhancement of banks' quality, enabling healthy financial sector and equally influencing the sector to be a strong in contributing to the real economy.

\section{Concept of Mergers and Acquisitions}

Mergers and acquisitions mean different things in different contexts [36]. The two terms are in many aspects treated as one or interchangeably. Sudarsanam [37] used merger, acquisition, takeover and buyout as synonyms (i.e. interchangeably) while the terms are sometimes treated as independently different [38].

Mergers and acquisitions act a popular means of growth for firms [11] [39]. 
This definition focuses not only on corporate growth, but also on alternatives to growth by internal or organic capital investment, although companies sometimes prefer external means of growth through acquisitions to internal growth. While Sudarsanam (20:1) suggests M\&As as a process "where two companies are combined to achieve certain strategic and business objectives". The objectives are not only significant to the companies alone but also to many other constituencies, such as workers, managers, competitors, communities and the economy in general.

Business strategic objectives are concerned with creating a sustainable competitive advantage for the firm. Therefore, their success or failure has great consequences for shareholders and lenders as well as the above constituencies. Madura and Fox [40] have a different definition as joint ventures and acquisitions as a strategy of foreign direct investment (FDI). While Lasserre [2] [41] concludes that it adds to the globalization of markets and a competitive advantage. That is, having a bigger size creates a marketing and competitive advantage in the global market. Conversely, Mitchell and Mulherin [42] perceive that M \& A is related to the reconstruction and consolidation of industries. Lehto and Lehtoranta [43], Petitt and Ferris [44] relate M \& As to the transfer of technology and knowledge to a target firm in order to have the opportunity to realize synergies. However, Motis [45] believes that the central tenet to $M$ \& As are twofold: to increase the value of merging firm so as to raise the future profits in the interest of the shareholders and to protect managers' interest which may not necessarily reflect the interest of the merging firm.

Sevenius [12] defined M \& A in relation to creating additional market shares, while Trautwein [46]; Altunbas [1] relates M \& As with empire building in order to have certain control of market shares. In contrast, Erixon [47] argues that $\mathrm{M}$ \& As is a legislative order to recapitalize a certain commercial banking industry for creating a promising economic capital base and competition, while Jensen [48] contrarily points out that $\mathrm{M} \&$ As is related to managerial motives and governance in order to create growth that will yield more managerial power and better remuneration. Huyghebaert and Luypaert [11] suggest that M \& $s$ is simply a means of growth for firms.

In view of the above definitions, one may conclude that the definition offered by Sudarsanam [20] seems to integrate the components of definitions propounded by different commentators. Mergers and Acquisitions can take place nationally or internationally. At the national level, $M$ \& A processed locally between two or more firms while at international tier, it occurs between firms of different countries which is called "cross-border M \& As" [1] [39]. If these companies are involved in mergers and acquisitions; Air France and KLM, SmithKline and Beecham, Lenovo and IBM are clear and good examples of international M \& As [2].

Mergers represent significant and vital corporate investments and therefore when mergers fail in achieving their objectives then the various stakeholders will 
suffer greatly [2]. According to Altunbas [1] "The meltdown in the mergers and acquisitions market and the stock market crash in 2000-2001 as well as 2008, the buyers in many of the deals suffered great losses. Example, RBS, Loyds TSP, taxpayers, etc. But some losses were as a result of unwise acquisitions made by their firms" (Figure 1).

Given the above definitions, it is apparent that merger and acquisition do not have a single meaning but in the course of this study would also refer to combining two or more firms as one with the view of achieving both strategic and business objectives [20].

\subsection{Types of Merger and Acquisition}

Mergers and Acquisitions are mainly classified in various ways [49]. The following five classifications best summarise the different types of $M \&$ As.

1) Horizontal M \& As: This refers to types of mergers and acquisitions that take place between two or more firms that are competing with one another because they engage in same line of business, offering the same or similar goods and services and in the same industry [38] [50] [51]. In other words, merger and acquisition of rival organizations, they may be services providers, products providers or both. For example, Aldi and Lidl Chain of stores or Wema Bank Plc. and National Bank of Nigeria Ltd.

2) Vertical M \& As: This is an example of a merger and acquisition relationship that is established between firms producing different goods or services for a specific finished product and within the same industry, e.g. supplier and producer, customer and supplier (buyer and seller) relationships [38] [51] [52].

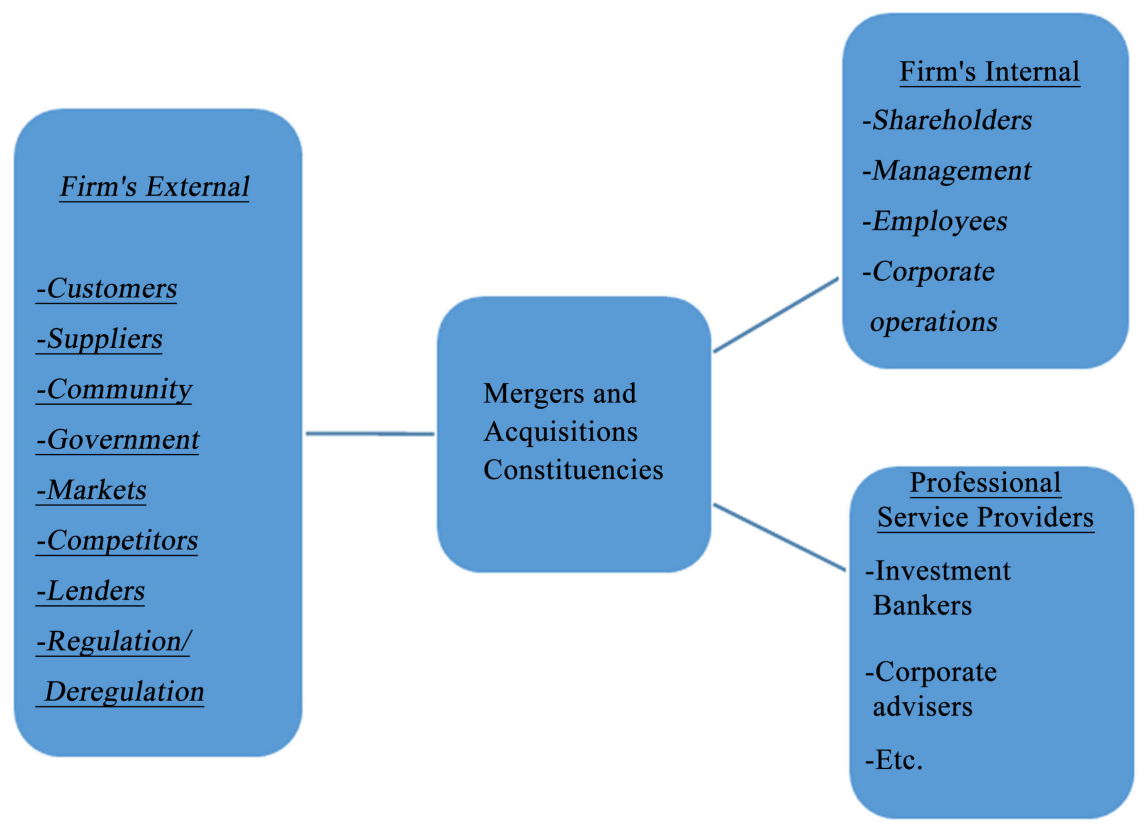

Figure 1. Mergers and Acquisitions stakeholders. Source: Altunbas [1] and Bolori [36]. 
3) Market-extension M \& As: This type of mergers and acquisitions relationship takes place between firms that engage in the same line of business but operates entirely in different markets [51]. For example, British Air and Ryan Air.

4) Product-extension M \& As: This occurs when two or more companies that sell different but related products, services or both in the same market are involved in merger and acquisition [51]. For example, a firm that produces toothbrushes and anther one that produces tooth paste.

5) Conglomeration $\mathbf{M} \&$ As: this includes a firm that wants to exploit economic of scale and diversifications by establishing mergers and acquisitions relationship with another firm or firms that operate in a number of unrelated businesses with the former [51], for instance, British Air and Morrison.

Given the above categorization, it could be suggested that the nature or type of business each firm does differs before establishing a new relationship or coming together. This categorization provides the basis for inquiry concerning the forms of $\mathrm{M}$ \& As.

\subsection{Pattern of Acquisitions}

Studies showed that there are two main forms of mergers and acquisitions [1]. However, the typology depends largely on the nature of the approach taken by the acquirer of a firm to the target firm, and also depending on the management of the target firm. The two forms of $M \& A$ include:

1) Friendly Mergers and Acquisitions: $M \&$ As negotiated within a friendly environment. The process begins when the management of one firm contacting the management of the target firm, normally through the investment bankers of each firm. The management of both firms keep the board of their directors informed about all the developments on the negotiations because at the end they will need the approval of their boards before proceeding with the approval of the shareholders and the approval normally goes through voting depending on the article of incorporation [7]. When the M \& As deal is made through the management of the concerned firm it is deemed friendly [20].

2) Hostile Mergers and Acquisitions: $M$ \& As negotiated within an aggressive environment [39]. The target management may resist takeover bids in order to secure their interests, such as jobs or empire and alternatively, they may resist in order maximize a favourable bargain paid by the bidder firm. Sudarsanam [39] argues that hostile M \& As happen when "tender offers to buy shares made directly to the target company shareholders, often without the support of the target management, generate more wealth for the acquire shareholders than mergers made with management support. In the UK, hostile acquisitions generate larger wealth than friendly mergers" [20].

The waves of mergers and acquisitions are normally triggered by two or more factors and the causes of M \& As' waves are differently defined by commentators largely based on their perceptions. 


\subsection{Drivers of Mergers and Acquisitions Waves}

Mergers and Acquisitions as a phenomenon used to occur in bursts interspersed with relative inactivity and a pattern known as the wave pattern of $M \&$ As [37]. There are several factors responsible for mergers and acquisitions depending on the situation that causes it [1]. The recent high level of financial crisis that leads to general economic crisis that triggers consolidation through mergers and acquisitions is described as a merger and acquisition wave, it is called a "wave" because it comes and goes in different magnitudes and degrees [53].

Between 1981 and 2000, Harford [15] identified 35 waves of M \& As with an average of 35 mergers per wave. While vast research has been conducted on the causes and effects of mergers, surprisingly very little studies exist on the causes of merger waves [54]. Mitchell and Mulherin [42] relate the wave as a result of industrial shocks that trigger reconstruction and consolidation of industries. In a contrasting view, Sevenius [12] suggests that "wave is predominately motivated by needs of additional market shares". In another perspective, it was argued that the M \& As waves are caused by stock market overvaluation [55] [56]. Macro-level liquidity component can propagate industry merger wave to cluster even if industry shocks do not [15]. Mergers and Acquisitions' wave can also be triggered by legislative initiatives through legislative policies [25].

Oberg and Holtstrom [57] claim that the "most common initial driving force for parallel $\mathrm{M} \& \mathrm{As}$ is when customers merge or acquire. In other words, $\mathrm{M} \& \mathrm{As}$ among the customers precede those of suppliers". It is believed that the target company industry is undergoing a merger wave but the acquiring company industry is not [58]. M \& A waves are mostly fuelled by the globalization of markets and competition [2]. Contrarily, Weston, J.F. and Weaver, P.S. [59] propagate that the recent M \& As wave which started in the mid-1990s was greatly influenced by global competition, change in technology and deregulation to cope up with the changing global economy. However, Lasserre (2:138) sees it as cross-border M \& A "mostly fuelled by the globalization of markets and competition". UNCTAD [60] is of same opinion with Lasserre [2]. Inferring from the above positions, it is clear that different commentators share different views concerning mergers and acquisitions, and waves are inevitable forces that can be caused by different factors.

\section{Results and Discussion}

The findings of paired t-test in Table 1 shows that bidders and targets' mean of each variable are statistically different at $5 \%$. This implies that there were statistically significant differences between the bidders and target in all aspects (variables) and therefore, the bidders were bigger and successful in performance than the targets.

The findings of paired t-test in Table 2 shows that bidders and targets' mean of each variable are statistically different at $5 \%$. The Table compared 3 years differences between the bidders and targets before mergers (2002 to 2004). This al- 
so implies that there were some significant differences between the two banks and that seems to be one of the factors that made bidders more successful and bigger than the targets.

The findings of paired t-test in Table 3 shows that bidders' pre-merger and post-merger performance's mean of each variable are statistically different at $5 \%$. Table 3 and Table 4, indicates the performance of bidders between different periods 5 and 3 years pre-merger (2000-2004) and 5 and 3 years post-merger (within 2006-2010) were compared. A number of significant differences were realised in all the variables between the two periods, and that may be the reason why bidder banks were successful in the pre-merger than during the post-merger. However, the findings differ from other studies' findings that scope and scale economies in mergers will influence costs efficiency, profit efficiency and market power [61] [62]. The current study findings are inconsistent with one another study which claims that small and medium firms achieve greater efficiency in their post mergers rather the big firms [63].

The result of paired t-test in Table 5 shows that bidders and non-merged banks' mean of each variable are statistically different at $5 \%$. Table 5 and Table 6 , indicates that a number of significant differences were statistically noted between bidder and non-merged banks between the last 5 and 3 years before (within 2000-2004) and immediate 5 and 3 years after the mergers (within 2006-2010). The previous results and the results in Table 4 and Table 5 have revealed the bidder was performing better than the non-merged banks during the pre-merger periods and they also found to be declining in the post-merger periods while the latter outperformed. The findings lent support to Sudarsanam [20] who found that "mergers and acquisitions more often destroy rather than enhance value for the acquirer shareholders". However, Said and Bouri [64] found that no efficiency has been achieved because the banks were better up in terms of cost and scope to yield more profitable result than combined in M\&As. Similarly, Kaur and Kaur [65] found that significant cost efficiencies are achieved after mergers but merging weak and strong banks do not yield success.

The findings of paired t-test in Table 6 shows that bidders and non-merged banks' mean of each variable are statistically different at $5 \%$.

\section{Conclusions}

The Nigerian Banking sub-sector has suffered problematic times since 1999, when the sector was facing problems of corporate governance as identified by the Central Bank of Nigeria. The study concludes that bidders were bigger and more successful in performance than the targets and that there were some significant differences between the two banks and that seems to be one of the factors that made bidders more successful and bigger than the targets. A number of significant differences were realised in all the variables between the two periods, and that may be the reason why bidder banks were successful in the pre-merger than during the post-merger. However, the findings differ from other studies' findings 
Table 1. Descriptive statistical differences of financial features among bidder and target banks.

\begin{tabular}{ccccc}
\hline Variables & \multicolumn{2}{c}{ Bidder Banks } & \multicolumn{2}{c}{ Target Banks } \\
\hline Bidder: & Mean & S.D & Mean & S.D \\
\hline $\begin{array}{c}\text { Natural logarithmic of total assets } \\
\text { Equity of total assets ratio }\end{array}$ & 13.05 & 1.19 & 11.61 & 1.10 \\
Loan loss provision to total loans & 13.80 & 6.48 & 11.76 & 27.50 \\
Ratio of loans to total assets & 4.35 & 6.59 & 5.54 & 2.56 \\
Ratio of deposits to total assets & 32.28 & 9.72 & 34.11 & 10.36 \\
Loan to total deposits ratio & 69.07 & 10.48 & 72.00 & 20.17 \\
$\quad$ Ratio of return to assets & 48.35 & 18.11 & 49.24 & 16.86 \\
\hline
\end{tabular}

Table 2. Descriptive statistical differences of financial features between bidder and target banks for 3 years (2002-2004) average.

\begin{tabular}{ccccc}
\hline Variables & Bidder Banks & Target Banks \\
\hline Bidder: & Mean & S.D & Mean & S.D \\
\hline $\begin{array}{c}\text { Natural logarithmic of total assets } \\
\text { Equity of total assets ratio }\end{array}$ & 13.34 & 1.07 & 12.09 & 1.04 \\
$\begin{array}{c}\text { Loan loss provision to total loans } \\
\text { Ratio of loans to total assets }\end{array}$ & 15.25 & 7.06 & 14.82 & 9.75 \\
$\quad$ Ratio of deposits to total assets & 4.15 & 8.45 & 4.45 & 3.76 \\
$\quad$ Loan to total deposits ratio & 63.40 & 8.79 & 34.42 & 7.59 \\
$\quad$ Ratio of return to assets & 50.85 & 17.14 & 49.87 & 14.07 \\
\hline
\end{tabular}

Table 3. Descriptive statistics on statistical differences in bidder banks' performance of 5 years (2000-2004) before and 5 years (2006-2010) after mergers.

\begin{tabular}{|c|c|c|c|c|}
\hline \multirow[t]{2}{*}{ Variables } & \multicolumn{2}{|c|}{ Before merger } & \multicolumn{2}{|c|}{ After merger } \\
\hline & Mean & S.D & Mean & S.D \\
\hline \multicolumn{5}{|l|}{ Bidder: } \\
\hline Natural logarithmic of total assets & 13.05 & 1.19 & 15.02 & 0.83 \\
\hline Equity of total assets ratio & 13.80 & 6.48 & 12.54 & 14.79 \\
\hline Loan loss provision to total loans & 4.35 & 6.59 & 6.98 & 11.28 \\
\hline Ratio of loans to total assets & 32.28 & 9.72 & 35.40 & 11.22 \\
\hline Ratio of deposits to total assets & 69.07 & 10.48 & 72.79 & 14.58 \\
\hline Loan to total deposits ratio & 48.35 & 18.11 & 50.85 & 19.27 \\
\hline Ratio of return to assets & 2.40 & 1.46 & -0.25 & -2.27 \\
\hline
\end{tabular}


Table 4. Descriptive statistics on statistical differences in bidder banks' performance of 3 years (2002-2004) before and 3 years after mergers (2006-2008).

\begin{tabular}{ccccc}
\hline Variables & \multicolumn{2}{c}{ Bidder Banks } & \multicolumn{2}{c}{ Target Banks } \\
\hline Dependable variable: & Mean & S.D & Mean & S.D \\
\hline $\begin{array}{c}\text { Natural logarithmic of total assets } \\
\text { Equity of total assets ratio }\end{array}$ & 13.34 & 1.07 & 14.98 & 0.86 \\
Loan loss provision to total loans & 15.25 & 7.06 & 16.34 & 7.42 \\
Ratio of loans to total assets & 4.15 & 8.45 & 5.39 & 11.14 \\
Ratio of deposits to total assets & 33.40 & 8.79 & 31.06 & 9.07 \\
Loan to total deposits ratio & 67.95 & 11.54 & 70.96 & 12.74 \\
Ratio of return to assets & 50.85 & 17.14 & 45.53 & 15.81 \\
\hline
\end{tabular}

Table 5. Descriptive statistics on statistical differences of financial features of bidder and non-merged banks for 5 years (2000-2004) before and 5 years (2006-2010) after average.

\begin{tabular}{ccccc}
\hline Variables & \multicolumn{2}{c}{ Bidder Banks } & \multicolumn{2}{c}{ Target Banks } \\
\hline & Mean & S.D & Mean & S.D \\
\hline Dependable variable: & & & & \\
Natural logarithmic of total assets & 14.00 & 1.25 & 15.02 & 0.83 \\
Equity of total assets ratio & 15.75 & 9.17 & 12.54 & 14.79 \\
Loan loss provision to total loans & 3.87 & 5.40 & 6.98 & 11.28 \\
Ratio of loans to total assets & 34.35 & 14.38 & 35.40 & 11.22 \\
Ratio of deposits to total assets & 70.11 & 17.50 & 72.79 & 14.58 \\
Loan to total deposits ratio & 55.58 & 26.94 & 50.85 & 19.27 \\
$\quad$ Ratio of return to assets & 2.23 & 2.68 & -0.25 & 8.28 \\
\hline
\end{tabular}

Table 6. Descriptive statistics on statistical differences of financial features of bidder and non-merged banks for 3 years (2002-2004) before and 3 years (2006-2008) after mergers.

\begin{tabular}{ccccc}
\hline Variables & \multicolumn{2}{c}{ Bidder Banks } & Target Banks \\
\hline Dependable variable: & Mean & S.D & Mean & S.D \\
\hline $\begin{array}{c}\text { Natural logarithmic of total assets } \\
\text { Equity of total assets ratio }\end{array}$ & 13.78 & 1.19 & 14.98 & 0.86 \\
Loan loss provision to total loans & 15.35 & 9.90 & 16.34 & 7.42 \\
Ratio of loans to total assets & 2.06 & 2.12 & 5.39 & 11.14 \\
Ratio of deposits to total assets & 32.35 & 13.15 & 31.06 & 9.07 \\
Loan to total deposits ratio & 70.62 & 20.12 & 70.96 & 12.74 \\
Ratio of return to assets & 57.27 & 31.59 & 45.53 & 15.81 \\
\hline
\end{tabular}


that scope and scale economies in mergers will influence costs efficiency, profit efficiency and market power. Merger and Acquisition seems as a means of achieving business strategy.

The study recommends that the managers of large and efficient banks seeking to go for merger and acquisition should halt from targeting small and less efficient banks because it will lead to operational inefficiency. Therefore, decision-makers of corporations should be very cautious whether to go for merger and acquisition as a source of enhancing operational efficiency or to go for other alternative options because it may be misleading. Policy makers at national levels should be very vigilant in promulgating policies related to mergers and acquisitions, especially in enforcing mergers on firms (forced mergers) due to its sensitivity.

\section{Conflicts of Interest}

The authors declare no conflicts of interest regarding the publication of this paper.

\section{References}

[1] Altunbas, Y. (2013) Mergers and Acquisitions. Lecture Note, Bangor University, North Wales.

[2] Lasserre, P. (2007) Global Strategic Management. 2nd Edition, Pal Grave Macmillan, Ltd., London.

[3] Beltratti, A. and Paladino, G. (2012) Is M and A Different During a Crisis? Evidence from the European Banking Sector. Journal of Financial Services, 33, 1.

[4] Adam, J.A. (2005) Banking Sector Reforms: The Policy Challenges of Bank Consolidation in Nigeria. 46th Nigerian Economic Society (NES), Annual Conference, Lagos, 23-25 August 2005.

[5] Molyneux, P., Altunbas, Y. and Gardener, E.P.M. (1996) Efficiency in European Banking. Wiley, New York City.

[6] Altumbas, Y. and Marques, D. (2007) Mergers and Acquisitions and Bank Performance in Europe: The Role of Strategic Similarities. Journal of Economics and Business, 60, 204-222. https://doi.org/10.1016/j.jeconbus.2007.02.003

[7] Gaughan, P.A. (1991) Mergers and Acquisitions. Harper Collins Publishers Inc., New York.

[8] Marchildon, P.G. (1991) Mergers and Acquisitions, USA. Edward Elgar Publishing Company, Cheltenham.

[9] Bengtsson, L. and Skarvad, P.H. (2001) Strategic Perspective.

[10] Buckley, A. (1995) Multinational Finance, England. Prentice-Hall, Upper Saddle River.

[11] Huyghebaet, N. and Luypaert, M. (2010) Antecedents of Growth through Mergers and Acquisitions: Empirical Results from Belgium. Journal of Business Research, 63, 392-403. https://doi.org/10.1016/j.jbusres.2009.06.003

[12] Sevenius, R. (2003) Företagsförväry-en introduktion. Studentlitteratur, Lund.

[13] Walter, G. and Barney, J. (1990) Research Notes and Communications: Management Objectives in Mergers and Acquisitions. Journal of Strategic Management, 11, 
79-86. https://doi.org/10.1002/smj.4250110107

[14] Khan, A.A. (2011) Mergers and Acquisitions in the Indian Banking Sector in Post Liberalization Regime. International Journal of Contemporary Business Studies, 2, 31-44. http://www.akpinsight.webs.com

[15] Harford, J. (2005) What Drives Merger Waves? Journal of Financial Economics, 77, 529-560. https://doi.org/10.1016/j.jfineco.2004.05.004

[16] Hogarty, T.F. (1970) Profits from Mergers: The Evidence of Fifty Years, Special Edition. St. John's Law Review, 44, 378-391.

[17] Gadiesh, O., Ormiston, C. and Rovit, S. (2003) Achieving on Merger Acquisitions Strategic Goals at Maximum Speed for Maximum Value. Journal of Strategy and Leadership, 31, 33-41.

[18] Buono, A.F. and Bowditch, J.L. (1989) The Human Side of Mergers and Acquisitions. Jossey-Bass, San Francisco.

[19] Schneider (2003) Trouble at the Top: A Sign of Deal Disorder, Mergers and Acquisitions. The Dealmaker's Journal, 107, 69-88.

[20] Sudarsanam, S. (2010) Creating Value from Mergers and Acquisitions: The Challenges. 2nd Edition, Prentice Hall, Upper Saddle River.

[21] Teply, P. and Starova, H. (2012) European Bank Mergers and Acquisitions: Do They Create Value for Shareholders? Financial Management. Charles University, Prague.

https://dspace.cuni.cz/bitstream/handle/20.500.11956/1799/RPTX_0_0_11230_0_27 5295_0_65702.pdf?sequence $=1$

[22] Sanusi, J.O. (2002) Promoting Good Corporate Governance: Issues and Challenges. Seminar Organised by FITC, Abuja, 4-6 June 2002, 1-9.

[23] Uchenna, W.A. and Okelue, D.U. (2012) Detecting Early Warning Bank Distress Signals in Nigeria: A Multi Discriminant Analysis Approach. Research Journal of Finance and Accounting, 3, 35-47.

[24] Ikhide, I.S. and Alawode, A.A. (2001) Financial Sector Reforms, Macroeconomic Instability and the Order of Economic Liberalization: The Evidence from Nigeria. African Economic Research Consortium, Nairobi, Paper 112.

[25] CBN (2004) Consolidating the Nigerian Banking Industry to Meet the Development Challenges of $21^{\text {st }}$ Century.

[26] Augustine, N.K. (2007) Impact of Nigeria's Bank Consolidation of Shareholders Return. African Institute for Economic Development and Planning, Dakar.

[27] CBN (2005) Statistical Bulletin: Volume 16 Annual Reports. The Director of Research and Statistics, Central Bank of Nigeria, Abuja.

[28] Sanusi, L.S. (2010) Global Financial Meltdown and the Reforms in the Nigerian Banking Sector. CBN Journal of Applied Statistics, 2, 93-108.

[29] Igbatayo, S. (2011) The Challenge of the Global Economic Crisis and Nigeria's Financial Markets' Stability. Journal of Emerging Trends in Economics and Management Sciences, 2, 497-503.

[30] CBN (2009) Annual Report and Statement of Account. Central Bank of Nigeria, Abuja. http://www.cbn.ng

[31] Nanto, K.D. (2009) The U.S. Financial Crisis: The Global Dimension with Implications for U.S. Policy. Congress Research Service, Washington DC.

[32] Ashamu, O.S. and Abiola, J. (2012) The Impact of Global Financial Crisis on Banking Sector in Nigeria. British Journal of Arts and Social Sciences, 4, 2046-9578. 
[33] World Bank (2009) Global Monitoring Report: A Development Emergency. Washington DC.

[34] Avgouleas, E. (2008) Financial Regulation, Behaviour Finance and Financial Credit Crisis in Search of a New Regulatory Model. http://papera.ssrn.com

[35] Merrouche, Q. and Habermeier, K. (2010) Caused of the Global Financial?_Evidence on the Drive Imbalances 1999-2007. IMF Working Paper, Monetary and Capital Markets Department.

[36] Bolori, B.U. (2015) The Impact of Forced Mergers and Acquisition of Banks on Nigerian Banking Industry. International Journal of Advanced Research in Engineering and Management, 1, 100.

[37] Sudarsanam, S. (2003) Creating Value from Mergers and Acquisitions, Challenges, Harlow. Pearson Education Ltd., London.

[38] Gaughan, P.A. (2007) Mergers, Acquisitions and Corporate Restructurings. John Wiley and Sons, Hoboken.

[39] Sudarsanam, P.S. (1995) Essence of Mergers and Acquisitions, Great Britain. Prentice Hall International, Upper Saddle River.

[40] Madura, J. and Fox, R. (2007) International Financial Management, London. Thomson Publishing Company, Stamford.

[41] Li, J., Lam, K.C.K., Karakowky, L. and Quan, G. (2003) Financial Resources and First Mover Advantages: A Case of Foreign Direct Investment in China. International Business Review, 12, 625-645. https://doi.org/10.1016/S0969-5931(03)00079-9

[42] Mitchell, M.L. and Mulherin, H.J. (1996) The Impact of Industry Shocks on Takeover and Restructuring Activity. Journal of Financial Economics, 42, 193-229. https://doi.org/10.1016/0304-405X(95)00860-H

[43] Lento, F. and Lehtoranta, O. (2004) Becoming an Acquirer and Becoming Acquired. Technological Forecasting and Social Change, 71, 635-650. https://doi.org/10.1016/S0040-1625(03)00086-6

[44] Petitt, B.S. and Ferris, K.R. (2013) Valuation for Mergers and Acquisitions. Pearson Education, London.

[45] Motis, J. (2007) Mergers and Acquisitions Motives.

[46] Trautwein, F. (1990) Merger Motives and Merger Prescriptions. Journal of Strategic Management, 11, 283-295. https://doi.org/10.1002/smj.4250110404

[47] Erixon, L. (1988) Ägande och inflytande i svenskt näringsliv, bilage 7, Orsaker till företagaskoncentrateon i utvecklade industriländer-en litteraturöversikt, statens offentliga utrtdningar: 38, Industridepartementet.

[48] Jensen, M.C. (1986) Agency Costs of Free Cash Flow, Corporate Finance and Takeover. American Economic Review, 76, 323-329.

[49] Atumbas, Y. and Marques, D. (2004) Mergers and Acquisitions and Bank Performance in Europe: The Role of Strategic Similarities. European Central Bank, Working Paper Series.

[50] Fiordelisi, F. (2009) Mergers and Acquisitions in European Banking. Palgrave Macmillan Publishers, London. https://doi.org/10.1057/9780230245402

[51] Wohlner, R. (2010) Mergers and Acquisitions: Definition. Investopedia. https://www.investopedia.com/terms/m/mergersandacquisitions.asp

[52] Coyle, B. (2000) Mergers and Acquisitions. Global Professional Publishing, London.

[53] Weston, J.F and Weaver, P.S. (2001) Mergers and Acquisitions. 
[54] Gugler, K., Mueller, D.C., Weichselbaumer, M. and Yurtoglu, B.B. (2012) Market Optimism and Merger Waves. Journal of Industrial Organization, 33, 159-175. https://doi.org/10.1016/j.ijindorg.2011.04.006

[55] Rhodes-Kropf, M. and Viswanathan, S. (2003) Market Valuation and Merger Waves. The Journal of Finance, 59, 2685-2718.

[56] Shleifer, A. and Vishing, R. (2003) Stock Market Driven Acquisitions. Journal of Financial Economics, 70, 295-311. https://doi.org/10.1016/S0304-405X(03)00211-3

[57] Oberg, C. and Holtsrom, J. (2006) Are Mergers and Acquisitions Contagious? Journal of Business Research, 59, 1267-1275. https://doi.org/10.1016/j.jbusres.2006.09.015

[58] Schmidt, B. and Duchin, R. (2013) Riding the Merger Wave: Uncertainty, Reduced Monitoring, and Bad Acquisitions. Journal of Financial Economics, 107, 69. https://doi.org/10.1016/j.jfineco.2012.07.003

[59] Weston, J.F. and Weaver, P.S. (1999) Perspectives on Mergers and Restructuring. Journal of Business Economics, 34, 29-33.

[60] UNCTAD (2008) Transnational Corporations and the Infrastructure Challenge. United Nations, New York and Geneva.

[61] Deloitte (2013) Mergers and Acquisitions Operational Synergies, Perspectives on the Winning Approach. Part 1 of the Ministries on Mergers and Acquisitions Operational Synergies (Perspectives on the Winning Approach).

[62] Akhavein, J.D., Berger, A.N. and Humphrey, D.B. (1997) The Effects of Mega Mergers on Efficiency and Prices: Evidence from a Bank Profit Function. Review of Industrial Organisation, 12.

[63] Sufian, F. (2004) The Efficiency Effects of Bank Mergers and Acquisitions in a Developing Economy: Evidence from Malaysia. International Journal of Applied Econometrics and Quantitative Studies, 1, 54-74.

[64] Said, B.H. and Bouri, A. (2013) Efficiency of French Bank Mergers and Acquisitions. Herald Journal of Education and General Studies, 2, 77-91.

[65] Kaur, P. and Kaur, G. (2010) Impact of Mergers on the Cost Efficiency of Indian Commercial Banks. Eurasian Journal of Business and Economics, 3, 27-50. 